\title{
Productivity of perennial cereal grasses and their strain mixture on drained peat soils
}

NSC «Institute of agriculture of NAAS», Mashy-nobu-divnykiv Str., 2, Chabany, 08162, Ukraine; e-mail: 1'kurgak_luki@ukr.net, ${ }^{2,3}$ shtakal@i.ua

The purpose. To determine productivity of efficiency of sowed cereal herbages depending on their species, sort structure and fertilizing in system of green (raw) conveyors on organogenic soils of Left-bank Forest-steppe. Methods. Field, laboratory, mathematical-and-statistical. Results. Productivity and terms of harvesting grasses and their mixtures of different terms of ripening on drained peat soils of Left-bank Foreststeppe are determined. Presence of herbages of different terms of ripening provides uniform receipt of cutted grass mass from the middle of May up to the end of September, as well as productivity of fields, which makes $7,5-13,2 \mathrm{t} /$ hectare of dry weight, exchange energy - 72,6-125,1 t/hectare, and feed unit $-5,7-11$ t/hectare. Conclusions. The best among early ripening grass herbages were the crops of orchardgrass of variety Kyiivska rannia 1 and meadow foxtail of variety Sarnenskyi rannii or their mixture with Awnless brome grass and meadow fescue. Among middle ripening grass herbages the best were fescue grass of variety Lyudmyla, reed canary grass of variety Sarnenska 40, Awnless brome grass of variety Arsen and mixture of meadow grasses with Awnless brome grass, fescue grass and reed canary grass. The highest productivity of late early ripening grass herbages is provided by adding into mixture Timothy-grass of variety Vyshgorodska, orchardgrass of variety Ukrainka and bent grass of variety Sarnenskyi piznya. Entering nitrogen fertilizers on drained peatlands is effective since the second year of use of grass herbages. Grass herbages on drained peatlands provide high fodder quality which is equated to quality of beans species. The content of raw protein in dry matter of the yield of different ripening types of grass herbages (on average over the years of research) was $14,5-16,0 \%$, and security of fodder unit was $126-147 \mathrm{~g}$.

Key words: drained peat lands, productivity of perennial herbages, fertilizers, selection of early ripening herbages, economic assessment.

https://doi.org/10.31073/agrovisnyk201809-03

The area of flood lands in the forest-steppe zone of Ukraine with peaty soils, which is characterized by high potential fertility, occupies about 300 thousand hectares, of which over than 200 thousand hectares are drained and use in agricultural production. However, the effectiveness of the use these lands is currently low due to a number of economic factors, reduction of cattle population, aggravation of environmental problems, etc.

Therefore, in order to increase the production of high-quality, competitive livestock products were dictated by the accession of Ukraine to the European Union, a sharp increase in the efficiency of fodder production, first of all, on dried peat soils is needed in the near future, whereas rain-fed lands are now predominantly used for grains and technical crops, and the share of fodder crops on it are insignificant.

According to existing recommendations for the agricultural use of such lands, they should be used mainly for the cultivation of perennial grasses, due to the need to combine the high productivity of meadow grasses with the improvement of the ecological situation in the river basins [1, 2, 3]. Moreover the advantage should be given to sowing for species of perennial grasses, because beans on these soils were not competitive and fragile[4, 5, 6, 7].

Therefore, further intensification of meadow fodder production involves the introduction into production a new high yield varieties of perennial grasses, different ripening types of mixed grass crops and grass crops variety mixes for the purpose of organizing on their basis the hay conveyors for the continuous receipt of green mass during the hay period and harvesting of fodder for the winter. However, until recently, such issues have not been properly studied, which was the subject of our research.

The purpose of research. The purpose of the research was to determine the productivity of high-yielding hay seeding grass canopies depending on their species and varietal composition and fertilization in the system of green (raw) conveyors on organogenic soils of the Left Bank Forest-steppe of Ukraine. 
Conditions and methods of research. The study was conducted in 2014-2017 on the drained peat soils of the floodplain of the Supoy River of Panfilska Experimental Station of NSC "Institute of Agriculture NAAS".

Soils of experimental plots is deep peatlands. Their upper layer $(0-30 \mathrm{~cm})$ has the following physical and agrochemical parameters: the degree of decomposition of peat over than $80 \%$, ash content $-45-50 \%$, density - 0,35-0,4 $\mathrm{g} / \mathrm{cm}^{3}, \mathrm{pH}$ aqueous - 7.5-7.7, the content of gross forms of nitrogen - 1.6-2.2\%, mobile phosphorus $-0.3-0.4 \%$, exchangeable potassium $-0.1-0.15 \%$. The content of humus is extremely high and is $-15-16 \%$.

The total area of the plot is $40 \mathrm{~m}^{2}$, the registration number is $28 \mathrm{~m}^{2}$, a fourfold repeating. The research was conducted in accordance with the methodology of the Institute of Forage and Agriculture of Podillya [8] in accordance with generally accepted field and laboratory methods using measurement and weight, calculation and comparative, chemical and mathematical and statistical methods.

Research results. The results of studies shown that the creation grass canopies of different ripening types allows to continue optimal times of mowing in the first cut for 10-15 days.

If you sow ultra-early-ripening species - foxtail (Alopecurus pratensis) and ultra-late-ripening - bent grass (Agrostis gigantea Roth), then these term can be increased to 20-25 days. In the second and third grasses cuts, the optimal period for harvesting fodder is increased to 25-35 days.

Was determined also an opportunity to create hay conveyors on the basis varieties of different ripening types of orchardgrass (Dactylis glomerata) variety (Kyyivska rannya-1, Muravka, Ukrainka), which makes it possible to continue the optimal time of cutting maturity for 7-15 days. Namely such organization of hay conveyors can provide continuous flow of mowing mass from mid-May to the end of September.

The dominant in early-ripening grass canopies in single-species crops during first four years of their using were Orchardgrass and Meadow foxtail, between medium term of maturity were reed canary grass, fescue grass (Festuca orientalis) Lyudmyla, Awnless brome grass (Bromus inermis) Arsen and their mixed grass with a share of sown culture of $71-95 \%$.

Between late-ripening types of grass canopies dominated the orchardgrass variety Ukrainka, the Timothygrass (Phleum pratense L.) Vyshgorodska, the bent grass (Agrostis gigantea Roth) Sarnenska piznya, which share in the net crops was in the range of $65-87 \%$.

At mixture of late-ripening types of grass canopies the advantage had the orchardgrass variety Ukrainka. At the 4th year of using grass canopies, the share of sown crops decreased by $5-10 \%$. The addition of nitrogen fertilizers in a dose of $\mathrm{N}_{90}$ increased in grass canopies the content of sown variety grasses by $2-5 \%$.

The perennial rye- grass (Lollium perenne) in grass variety mixes with sorts of Orion, Svyatoshynsky, Andriana 80, and the meadow fescue grass (Festuca pratensis) in mixes with red fescue grass (Festuca rubra L.) dominated only in the first year of the use of grass canopies with a share of $70-90 \%$. On 3-4 year, they significantly thin out and their proportion dropped to $37-51 \%$ and less.

Studies shown that on the depleted peat soils of the Forest-steppe, the productivity of different ripening types of grass crops canopies throughout the years of research, including dry years, was stable high (Table).

The yield of green mass on the average for 2014-2017 against the background of $\mathrm{P}_{45} \mathrm{~K}_{120}$ fluctuated within the range of 40.3-70.9 $\mathrm{t} / \mathrm{ha}$, and the productivity at the exit from 1 ha of dry weight - in the range of 7.5-11.5 $\mathrm{t}$, fodder units - 5,7-8,3 tons, exchange energy - 72,6-108,4 GJ, digestible protein - 0,80-1,45 tons. The productivity of sowing grass canopies increased by 1,1-1,2 times if added for $\mathrm{P}_{45} \mathrm{~K}_{120}$ nitrogen at a dose of $\mathrm{N}_{90}$.

Among early-ripening type of grass canopy, the most productive were the mixture of orchardgrass (Dactylis glomerata) variety Kyyivska rannya-1 with meadow foxtail (Alopecurus pratensis) variety Sarnenskyi rannii or with Awnless brome grass (Bromus inermis) and meadow fescue grass (Festuca pratensis) which provided obtaining on the background $\mathrm{P}_{45} \mathrm{~K}_{120}$ 9.5-9.7 t/ha dry mass and 92-96 GJ/ha of exchange energy and 7.1-7.8 t/ha of fodder units, while on the background of $\mathrm{N}_{45} \mathrm{R}_{45} \mathrm{~K}_{120}-11.0-11.4 \mathrm{t} / \mathrm{ha}$, 110-117 GJ / ha and 9.0-9.8 $\mathrm{t} /$ ha respectively. Among of the middle ripening grass canopy the maximum productivity provided by reed canary grass (Digraphis arundinacea L.) variety Sarnenska 40 and mixture with fescue grass (Festuca orientalis) and Awnless brome grass (Bromus inermis). 
Productivity of species, varieties, mixed grass crops and grass crops variety mixes depending on fertilizer, average for 2014-2017, $\mathrm{t}$ / ha

\begin{tabular}{|c|c|c|c|c|}
\hline $\begin{array}{l}\text { Types and varieties of grass, mixed grass crops and norms of } \\
\text { sowing of seeds, } \mathrm{kg} / \mathrm{ha}\end{array}$ & $\begin{array}{l}\text { dry } \\
\text { mass }\end{array}$ & $\begin{array}{l}\text { exchange } \\
\text { energy }\end{array}$ & $\begin{array}{l}\text { fodder } \\
\text { units }\end{array}$ & $\begin{array}{l}\text { digestible } \\
\text { protein }\end{array}$ \\
\hline 1 & 2 & 3 & 4 & 5 \\
\hline \multicolumn{5}{|l|}{$\mathrm{P}_{45} \mathrm{~K}_{120}$} \\
\hline \multicolumn{5}{|l|}{$\begin{array}{ll}\text { Early maturing grass canopies } \\
\end{array}$} \\
\hline Alopecurus pratensis) variety Sarnenskyi rannii - 22 & 8,1 & 78,0 & 6,1 & 0,77 \\
\hline orchardgrass (Dactylis glomerata) variety Kyyivska rannya-1 - 25 & 9,0 & 87,6 & 6,9 & 0,97 \\
\hline Alopecurus pratensis) $-11+$ orchardgrass $-12,5$ & 9,5 & 91,6 & 7,1 & 1,00 \\
\hline $\begin{array}{l}\text { orchardgrass (Dactylis glomerata) variety Kyyivska rannya- }-17,5+ \\
\text { Awnless brome grass (Bromus inermis), Arsen }-4,2+\text { fescue grass } \\
\text { (Festuca orientalis) Katrina }-3,8\end{array}$ & 9,7 & 96,1 & 7,8 & 1,06 \\
\hline \multicolumn{5}{|l|}{ Medium maturity grass canopies } \\
\hline Awnless brome grass (Bromus inermis), Arsen- 28 & 10,1 & 99,6 & 8,0 & 1,10 \\
\hline Awnless brome grass (Bromus inermis), Topaz - 28 & 9,6 & 94,4 & 7,5 & 1,07 \\
\hline Awnless brome grass (Bromus inermis), Gelius - 28 & 9,6 & 93,1 & 7,3 & 1,02 \\
\hline orchardgrass variety Muravka- 25 & 9,7 & 94,8 & 7,5 & 1,02 \\
\hline fescue grass Lyudmyla - 25 & 10,6 & 101,8 & 8,0 & 1,08 \\
\hline fescue grass (Festuca orientalis) Zakat - 25 & 10,1 & 96,4 & 7,5 & 1,05 \\
\hline reed canary grass (Digraphis arundinacea L.) Sarnenska $40-12$ & 11,5 & 108,6 & 8,3 & 1,14 \\
\hline $\begin{array}{l}\text { meadow fescue grass (Festuca pratensis) } \\
\text { grass (Festuca rubra L.) Olenka }-6\end{array}$ & 8,6 & 84,1 & 6,6 & 0,96 \\
\hline $\begin{array}{l}\text { The perennial rye- grass (Lollium perenne) variety Orion }-7,5+ \\
\text { Svyatoshynskyy }-7,5+\text { Adriana } 80-7,5+ \\
\text { red fescue grass (Festuca rubra L.) Olenka }-2\end{array}$ & 7,5 & 72,6 & 5,7 & 0,80 \\
\hline $\begin{array}{l}\text { Awnless brome grass (Bromus inermis), Arsen }-9,3+\text { fescue grass } \\
\text { (Festuca orientalis) Zakat }-8,3+\text { orchardgrass variety Muravka }-8,5\end{array}$ & 10,2 & 97,5 & 7,5 & 1,05 \\
\hline $\begin{array}{l}\text { Awnless brome grass (Bromus inermis), Arsen }-9,3+\text { fescue grass } \\
\text { (Festuca orientalis) Zakat }-8,5+\text { reed canary grass (Digraphis } \\
\text { arundinacea L.) Sarnenska } 40-4\end{array}$ & 11,0 & 106,2 & 8,3 & 1,14 \\
\hline \multicolumn{5}{|l|}{ Late maturity grass canopies } \\
\hline Timothy-grass (Phleum pratense L.) Vyshgorodska - 15 & 8,9 & 87,1 & 6,9 & 0,95 \\
\hline Timothy-grass (Phleum pratense L.) Sarnenska 35- 15 & 8,9 & 84,3 & 6,5 & 0,89 \\
\hline orchardgrass variety Ukrainka - 25 & 10,2 & 97,6 & 7,5 & 1,06 \\
\hline bent grass (Agrostis gigantea Roth) Sarnenska piznya - 11 & 8,6 & 83,0 & 6,5 & 0,91 \\
\hline $\begin{array}{l}\text { Timothy-grass (Phleum pratense L.) Vyshgorodska }-5+ \\
\text { orchardgrass variety Ukrainka }-8,3+\text { bent grass (Agrostis gigantea } \\
\text { Roth) Sarnenska piznya }-3,8\end{array}$ & 10,1 & 96,0 & 7,4 & 1,05 \\
\hline
\end{tabular}


Continuation of Table

\begin{tabular}{|c|c|c|c|c|}
\hline 1 & 2 & 3 & 4 & 5 \\
\hline \multicolumn{5}{|l|}{$\mathrm{N}_{90} \mathrm{P}_{45} \mathrm{~K}_{120}$} \\
\hline \multicolumn{5}{|l|}{ Early maturing grass canopies } \\
\hline Alopecurus pratensis) variety Sarnenskyi rannii - 22 & 9,8 & 98,1 & 7,9 & 1,03 \\
\hline orchardgrass (Dactylis glomerata) variety Kyyivska rannya-1 - 25 & 10,8 & 107,6 & 8,6 & 1,25 \\
\hline Alopecurus pratensis) - $11+$ orchardgrass $-12,5$ & 11,0 & 110,4 & 9,0 & 1,22 \\
\hline $\begin{array}{l}\text { orchardgrass (Dactylis glomerata) variety Kyyivska rannya-1 - 17,5+ } \\
\text { Awnless brome grass (Bromus inermis), Arsen }-4,2+ \\
\text { fescue grass (Festuca orientalis) Katrina }-3,8\end{array}$ & 11,4 & 117,3 & 9,8 & 1,34 \\
\hline \multicolumn{5}{|l|}{ Medium maturity grass canopies } \\
\hline Awnless brome grass (Bromus inermis), Arsen-28 & 12,0 & 117,0 & 9,2 & 1,33 \\
\hline Awnless brome grass (Bromus inermis), Topaz - 28 & 11,3 & 110,7 & 8,8 & 1,25 \\
\hline Awnless brome grass (Bromus inermis), Gelius -28 & 11,3 & 109,6 & 8,6 & 1,21 \\
\hline orchardgrass variety Muravka - 25 & 11,5 & 113,4 & 9,1 & 1,27 \\
\hline fescue grass Lyudmyla -25 & 12,2 & 120,9 & 9,8 & 1,36 \\
\hline fescue grass (Festuca orientalis) Zakat -25 & 11,9 & 117,1 & 9,3 & 1,30 \\
\hline reed canary grass (Digraphis arundinacea L.) Sarnenska $40-12$ & 13,2 & 129,5 & 10,3 & 1,45 \\
\hline $\begin{array}{l}\text { meadow fescue grass (Festuca pratensis) Katrina }-17,5+\text { red fescue } \\
\text { grass (Festuca rubra L.) Olenka }-6\end{array}$ & 9,5 & 93,9 & 7,5 & 1,06 \\
\hline $\begin{array}{l}\text { The perennial rye- grass (Lollium perenne) variety Orion }-7,5+ \\
\text { Svyatoshynskyy }-7,5+\text { Adriana } 80-7,5+ \\
\text { red fescue grass (Festuca rubra L.) Olenka }-2\end{array}$ & 8,7 & 84,1 & 6,6 & 0,90 \\
\hline $\begin{array}{l}\text { Awnless brome grass (Bromus inermis), Arsen }-9,3+\text { fescue grass } \\
\text { (Festuca orientalis) Zakat }-8,3+\text { orchardgrass variety Muravka }-8,5\end{array}$ & 12,0 & 118,1 & 9,4 & 1,28 \\
\hline $\begin{array}{l}\text { Awnless brome grass (Bromus inermis), Arsen }-9,3+\text { fescue grass } \\
\text { (Festuca orientalis) Zakat }-8,5+\text { reed canary grass (Digraphis } \\
\text { arundinacea L.) Sarnenska } 40-4\end{array}$ & 12,9 & 125,1 & 9,8 & 1,36 \\
\hline \multicolumn{5}{|l|}{ Late maturity grass canopies } \\
\hline Timothy-grass (Phleum pratense L.) Vyshgorodska - 15 & 11,1 & 111,0 & 9,0 & 1,23 \\
\hline Timothy-grass (Phleum pratense L.) Sarnenska 35-15 & 10,3 & 102,6 & 8,2 & 1,11 \\
\hline orchardgrass variety Ukrainka - 25 & 11,8 & 117,5 & 9,2 & 1,34 \\
\hline bent grass (Agrostis gigantea Roth) Sarnenska piznya - 11 & 9,4 & 93,6 & 7,5 & 1,05 \\
\hline $\begin{array}{l}\text { Timothy-grass (Phleum pratense L.) Vyshgorodska }-5+\text { orchardgrass } \\
\text { variety Ukrainka }-8,3+\text { bent grass (Agrostis gigantea Roth) Sarnenska } \\
\text { piznya }-3,8\end{array}$ & 11,2 & 108,7 & 8,5 & 1,25 \\
\hline \multicolumn{5}{|l|}{$\mathrm{HIP}_{05}$ by factors, $\mathrm{t} / \mathrm{ha}:$} \\
\hline grass canopy & 0,56 & & - & \\
\hline fertilization & 0,18 & & - & \\
\hline
\end{tabular}

Note. *exchange energy, GJ/ha

They dominated over other types and mixtures of grass on average in all years of research at 1.5-2.0 $\mathrm{t} /$ ha dry mass.

The high productivity also characterized the fescue grass (Festuca orientalis) variety Lyudmyla and Awnless brome grass (Bromus inermis) - Arsen which provided output of 1 ha of dry mass on the background of $\mathrm{P}_{45} \mathrm{~K}_{120}-10.6-11.5$ tonnes, and on the background of $\mathrm{N}_{45} \mathrm{R}_{45} \mathrm{~K}_{120}-12,0-13,2$ tonnes and the exchange energy respectively - 106,2-108,6 and 118,1-129,5 GJ and fodder units - 8,0-8,3 and 9,4-11,5 t.

The best among late maturity were grass canopy, formed on the basis of late maturity the orchardgrass (Dactylis glomerata) variety Ukrainka and mixtures Timothy-grass (Phleum pratense L.) Vyshgorodska and the bent grass (Agrostis gigantea Roth) Sarnenska piznya. 
The productivity of these mixtures stood on the background of $\mathrm{P}_{45} \mathrm{~K}_{120}-10.1-10.2 \mathrm{t} /$ ha dry mass, 96.0$97.6 \mathrm{GJ} /$ ha of exchange energy or $8.2 \mathrm{t} /$ ha of fodder units and on the background of $\mathrm{N}_{45} \mathrm{R}_{45} \mathrm{~K}_{120}$ respectively - $11.1-11.8 \mathrm{t} / \mathrm{ha}, 111-117.5 \mathrm{GJ} / \mathrm{ha}$ or 9.3-10.3 $\mathrm{t} / \mathrm{ha}$.

The efficiency of application of nitric fertilizer at the dose $\mathrm{N}_{90}$ at the 1 st year of use of grass canopy was low, the increment of yield was insignificant with payback from $1 \mathrm{~kg}$ of mineral nitrogen $9 \mathrm{~kg}$ of dry mass.

In the following years the efficiency of application of this dose on the background of $\mathrm{P}_{45} \mathrm{~K}_{120}$ increased, that providing the increase by the yield of dry mass $1.1-2.2 \mathrm{t} /$ ha with a payback from $1 \mathrm{~kg}$ of nitrogen $18-24 \mathrm{~kg}$ of yield dry mass.

The orchardgrass (Dactylis glomerata), Awnless brome grass (Bromus inermis), Timothy-grass (Phleum pratense L.) reacted to nitrogen better, with a payback from $1 \mathrm{~kg}$ of nitrogen with a yield of dry mass $-20-24 \mathrm{~kg}$

The productivity of most grass canopy, formed on the basis of perennial grasses and their mixed grass and grass variety mixes was stable during the years of using.

Grass canopies with the perennial rye- grass (Lollium perenne) and fescue grass (Festuca orientalis), the productivity of which maintained at a high level only in the first year of using were exception.

Starting from the 2nd year, due to liquefaction and fallout from the composition of the cenozes of the specified types of grass, the productivity of the mowing grasses formed on their basis dropped sharply to 6-7 $\mathrm{t} /$ ha of dry mass, that on $30-45 \%$ less than other grass canopies.

The distribution of yields by hays on drained peat soils was fairly uniform with a share of the 1st hay of $40-51 \%$, 2nd $-28-34 \%$ and $3 r d-20-27 \%$, and the uneven distribution, pronounced by the coefficient of variation of $24-32 \%$. Orchardgrass (Dactylis glomerata), awnless brome grass (Bromus inermis) and reed canary grass (Digraphis arundinacea L.) characterized the more uniform distribution of yields by hays.

Grass canopies on drained peatlands provide a high quality fodder. The content of raw protein in the dry mass of the yield of different ripening types of grass canopies on average during years of research was $14,5-16,0 \%$, protein $-13,3-14,9 \%$, raw fat $-3,0-3,4 \%$, raw cellulose - $27-29 \%$, non-nitrogen extractive substances (NES) - 44-46\%. Such a high content of raw protein amount to it content among bean species on the adjacent chernozeums and gray forest soils $[9,10]$. The permeability of dry mass in vitro fluctuated within $60-63 \%$. At the same time, the supply of fodder unit with digestible protein was high and amounted to 126$147 \mathrm{~g}$. Fodder nutrition in content of fodder in dry mass fluctuated within $0.74-0.82$ fodder units, and the energy intensity of content the exchange energy was $9.2-9,5 \mathrm{MJ} / \mathrm{kg}$ of dry mass.

Grass fodder of grass canopies characterized by high quality and by mineral composition. In particular, in the dry mass of the fodder, the phosphorus content $(P)$ fluctuated within $0.37-0.40 \%$, calcium $(\mathrm{Ca})-0.58$ $0.70 \%$, magnesium $(\mathrm{Mg})-0.25-0.42 \%$, potassium $(\mathrm{K})-2.0-2.2 \%$ with $\mathrm{Ca} / \mathrm{P}$ ratios $-1.5-1.6$ and $\mathrm{K} / \mathrm{Ca}+\mathrm{Mg}$ - 2.2-2.4. By mineral composition, the fodder of perennial grasses in general consistented for zootechnical standards of feeding farm animals. In the grass of the 3rd cut, phosphorus and potassium were less accumulated in comparison with the first one.

On the basis of the research, a model of a green conveyor was developed that based on different ripening types of grass canopies that provides a continuous unified income of cutting green mass during 145 days in the period from May 20 to October 10 from an area of 100 hectares for feeding of green fodder for 250 cows during simultaneous harvesting for the winter period $400 \mathrm{t}$ hay or $914 \mathrm{t}$ haylage. The cultivation of meadow grasses in drained peatlands of Forest-Steppe for the introduction of $\mathrm{P}_{45} \mathrm{~K}_{120}$ and $\mathrm{N}_{90} \mathrm{R}_{45} \mathrm{~K}_{120}$ provided a conditionally net profit of 9-15 and 10-16 thousand UAH / ha, respectively. The profitability of the production of grass fodder was better on the background of $\mathrm{P}_{45} \mathrm{~K}_{120}$ and amounted to $126-185 \%$ with a prime cost of 1 ton of fodder units at the level of 980-1200 UAH. The best results were obtained on middle ripening grass canopies with sowing of reed canary grass (Digraphis arundinacea L.), fescue grass variety Lyudmyla, Awnless brome grass (Bromus inermis), Arsen and their mixtures which ensured receiving the largest a conditionally net profit and the level of profitability of production, and the lowest prime cost of $1 \mathrm{t}$ of fodder units. The introduction of $\mathrm{N}_{90}$ in the first year of grass canopies using was ineffective. Economic expediency introduction of this dose of nitrogen manifested itself from the second year of the using of grass canopies. 


\section{Conclusions}

New high-yielding varieties of the main species and varieties of grass canopy provide the productivity of canopy on the drained peat soils of $7-11 \mathrm{t} /$ ha of fodder units and the continuous income of cutting mass from mid-May to the end of September.

It is necessary to create different maturing grass canopy for the organization of the hay conveyors in order to continue the optimal time of mowing green mass in the first hay for 10-15 days, and in the second the third hays - for 25-35 days.

The best among early maturing grass canopies by productivity are sowing of orchardgrass (Dactylis glomerata) variety Kyyivska rannya-1 with Alopecurus pratensis) variety Sarnenskyi rannii or their mixture with Awnless brome grass (Bromus inermis) and fescue grass (Festuca orientalis).

Among midle-maturing - the best net sowing were fescue grass variety Lyudmyla, reed canary grass (Digraphis arundinacea L.) Sarnenska 40, awnless brome grass (Bromus inermis) Arsen, and mixture of perennial grasses by awnless brome grass (Bromus inermis), fescue grass and reed canary grass (Digraphis arundinacea L.).

The highest productivity of late maturity grass canopies is provided by the inclusion in mixed grass Timothy-grass (Phleum pratense L.) variety Vyshgorodska, orchardgrass variety Ukrainka and bent grass (Agrostis gigantea Roth) Sarnenska piznya.

It is also possible the organize of hay conveyors by different maturing varieties of orchardgrass (Dactylis glomerata) varieties Kyyivska rannya-1, Muravka, Ukrainka.

The introduction of nitrogen fertilizers on the drained peat soils is effective since the second year of using grass canopies.

In view of the high availability of these soils with nitrogen, the quality of fodder from grasses is not inferior to legumes grasses which growing on mineral soils adjacent them.

\section{References}

1. Kurhak V.H. (2010). Luchni ahrofitotsenozy. [Grassland agrophytocenoses]. Kyiv: DIA. P. 374. [in Ukrainianl.

2. Petrychenko V.F., Hadzalo Ya.M., Zaryshnyak A.S. (2014). Kontseptsiya efektyvnoho sil's'kohospodars'koho vykorystannya zemel' humidnoyi zony Ukrayiny [The concept of efficient agricultural land use humid zone of Ukraine]. Kyiv: NNTs «IZ NAAN». P. 54. [in Ukrainian].

3. Ryzhuk S.M., Slyusar I.T. (2006). Ahroekolohichni osnovy efektyvnoho vykorystannya osushuvanykh hruntiv Polissya i Lisostepu Ukrayiny. [Agroecological bases of effective use drained soils Polesie and foreststeppe Ukraine]. Kyiv: Ahrarna nauka. P. 421. [in Ukrainian].

4. Kurhak V.H., Sukaylo M.V. (2011). Produktyvnist' bobovo-zlakovykh travostoyiv. [Productivity legume-grass mixtures]. Visnyk ahrarnoyi nauky. Vol 8. P. 21-25. [in Ukrainian].

5. Shtakal M.I. (1992). Mozhlyvosti stvorennya zlakovo-bobovykh travostoyiv na torfovykh gruntakh. [Opportunities for grass-legume mixtures on peat soils]. Kormy i kormo vyrobnytstvo. Vol. 34. P. 23-27. [in Ukrainian].

6. Mashchak Ya.l., Kobyrenko Yu.O. (2014). Vidnovlennya vyrodzhenoho travostoyu shlyakhom vsivannya bobovykh trav u nerozroblenu dernynu. [Restoring vegetation degenerate by vsivannya legumes in undeveloped turf]. Kormy i kormovyrobnytstvo. Vol. 79. P.93-97. [in Ukrainian].

7. Makarenko P.S. (1982). Bobovo-zlakovi travosumishky dlya stvorennya vysokoproduktyvnykh zroshuvanykh pasovyshch $v$ Lisostepu URSR. [Legume-grass travosumishky to create highly irrigated pastures in forest-steppe of the USSR]. Visnyk silskohospodarskoi nauky. Vol 7. P. 26-29. [in Ukrainian].

8. Peeters A. (2015). Synthesis of systems and region levels. Grassland Science in of European grassland typologies at plot, farm Europe 20. P. 116-118.

9. Babych A.O., Kulyk M.F., Makarenko P.S. (1998). Metodyka provedennya doslidiv z kormo vyrobnytstva i hodivli tvaryn. [Methods of experiments with forage production and animal nutrition]. Kyiv: Ahrarna nauka. P. 79. [in Ukrainian]. 
10. Petrychenko V.F., Kurhak V.H. (2013). Kul'turni sinozhati ta pasovyshcha Ukrayiny. [Cultural grasslands and pastures Ukraine]. Kyiv: Ahrarna nauka. P. 412. [in Ukrainian].

11. Shtakal M.I. (2013). Rozvytok luchnoho kormo vyrobnytstva na osushenykh torfovykh gruntakh. [Development meadow fodder production on drained peat soils]. Kormy i kormo vyrobnytstvo. Vol.84. P. 229-235. [in Ukrainian]. 